\title{
Molecular Identification and Phylogenetic Relationships of Threadfin Breams (Family: Nemipteridae) Using mtDNA Marker
}

\author{
Vaithilingam RAVITCHANDIRANE, Vaithianathan GEETHA, Vijayan \\ RAMYA ${ }^{1}$, Bilavendiran JANIFER ${ }^{1}$, Muthusamy THANGARAJ ${ }^{2 *}$, Jayachandran \\ SUBBURAJ ${ }^{2}$, Vellaichamy RAMANADEVI², Takshnamurthy GANESAN ${ }^{3}$ \\ ${ }^{1}$ Kanchi Mamunivar Centre for Post-Graduate Studies, Department of Zoology, 605008 Pondicherry, India \\ ${ }^{2}$ Annamalai University, Centre of Advanced Study in Marine Biology, 608502 Parangipettai, \\ Tamilnadu, India; coralholder@yahoo.com (*corresponding author) \\ ${ }^{3}$ Tagore Arts College, Department of Plant Science, 605008 Pondicherry, India
}

\begin{abstract}
Cytochrome c oxidase-1 gene sequences of mitochondrial genome were analyzed for species identification and phylogenetic relationship among the commercially important Nemipterus species. Sequence analysis of COI gene clearly indicated that all the nine fish species fell into distinct clads, which are genetically distant from each other and exhibited identical phylogenetic reservation. All the COI gene sequences provide sufficient phylogenetic information and evolutionary relationship to distinguish the nine Nemipterus species unambiguously. As per the neighbour-joining $(\mathrm{NJ})$ and maximum likelihood $(\mathrm{ML})$ trees, all the nine species are genetically distant from each other and exhibited identical phylogenetic reservation. Based on the NJ and ML phylogenetic trees $N$. mesoprion, $N$. zysron, $N$. hexodon, $N$. nematophorus, $N$. virgatus and $N$. bipunctatus were closely related with high bootstrap value (97). The overall mean Kimura two parameter (K2P) distances between the nine species was 0.109. The intra species K2P distance was high in $N$. japonicus (0.069) followed by $N$. peronii (0.050) and $N$. mesoprion (0.002). This study proves the use of mtDNA COI gene sequence based approach is an alternative tool for identifying fish species at a faster pace.
\end{abstract}

Keywords: cytochrome oxydase-1, intraspecific, Nemipterus, phylogeny; taxonomy

Abbreviation used: mtDNA: mitochondrial DNA, CO1: Cytochrome Oxydase-1, NJ: Neighbour-joining, ML: Maximum Likelihood, K2P: Kimura Two Parameter, FAO: Food and Agricultural Organization, dNTP: Deoxyribonucleotide triphosphate, mM: Milli Molar, TAE: Tis Acetate EDTA

\section{Introduction}

The threadfin breams, also called pink perch constitute an important demersal finfish resource in the Indian EEZ. These fishes are abundant beyond $50 \mathrm{~m}$ but show higher concentration at 100-200 m depth as revealed by the exploratory surveys and experimental fishing (Murty et al., 2001). Threadfin breams are one of the most dominant components among the demersal fisheries of India being exploited by commercial trawlers and available all the entire year (Russell, 1990). The classification of nemipterid fishes into different taxa is much confusing as, they are the members of one of the most confusing families (Russell, 1990). Threadfin bream's catches are usually mixed in India with representation of three or more species of genus Nemipterus (Murty et al., 2001). They are rarely reported as separate species because of problems in proper identification (Pawar et al., 2011). Morphometric characters and colour patterns are the most useful taxonomic tools which helps in segregation of fish species (Russell, 1990). But taxonomic ambiguity exists for juvenile and pre-adult fishes and it may lead to another synonym to a fish species. DNA-based approaches for taxon diagnosis exploiting DNA sequence diversity among species can be used to identify fishes and resolve taxonomic ambiguity including the discovery of new/cryptic species (Hebert et al., 2003). As there is no paternal contribution of mtDNA and no known recombination between mitochondrial genomes, the mtDNA genes are selected for species identification (Thangaraj and Lipton, 2011). Earlier studies have demonstrated that the COI gene is appropriate and accepted as a universal barcode for discriminating between closely related species across diverse animal phyla and this has been used for marine and freshwater fishes (Hebert et al., 2003; Hubert et al., 2008; Lakra et al., 2011; Ward et al., 2005).

Considering the importance of molecular identification and as there are no attempts to study genetic relation- 
14

ship between various Nemipterus species, in spite of its economic importance and significant contribution in marine fishery, the present study was achieved. In this study, the genetic difference between four commonly available threadfin bream species in Bay of Bengal and other $\mathrm{Ne}^{-}$ mipterus species were assessed using mitochondrial gene sequence.

\section{Materials and methods}

\section{Sample collection}

Forty specimens from four species were collected from the Pondicherry coastal waters $\left(11^{\circ} 46^{\prime}\right.$ and $12^{\circ} 03^{\prime} \mathrm{N}$ and $79^{\circ} 36^{\prime}$ and $79^{\circ} 53^{\prime} \mathrm{E}$ ). Immediately after the collection specimens were kept in the iceboxes for further studies. All the fishes were identified up to the species level using the FAO Fish Identification Sheets (Thomson, 1984) and further confirmation were carried out at Zoological Survey of India, Southern Regional Centre, Chennai. The voucher specimens are maintained in the Department of Zoology, Kanchi Mamunivar Centre for Post-Graduate Studies, Pondicherry. Approximately $100 \mathrm{mg}$ of white muscle tissue and fin-clips from two to five individuals of each species were preserved in $95 \%$ ethanol and stored at $4^{\circ} \mathrm{C}$ until used.

\section{DNA isolation}

The DNA was isolated by standard Proteinase-K/Phenol-Chloroform-ethanol method (Sambrook et al., 1989) and the concentration of isolated DNA was estimated us- ing a UV spectrophotometer. The DNA was diluted in TAE buffer to a final concentration of $100 \mathrm{ng} / \mu \mathrm{L}$.

\section{Amplification and sequencing}

The COI gene was amplified in a $50 \mu \mathrm{L}$ volume with $5 \mu \mathrm{L}$ of $10 \mathrm{X}$ Taq polymerase buffer, $2 \mu \mathrm{L}$ of $\mathrm{MgCl}_{2}(50 \mathrm{mM}), 0.25 \mu \mathrm{L}$ of each dNTP $(0.05 \mathrm{mM})$, $0.5 \mu \mathrm{L}$ of each primer $(0.01 \mathrm{mM}), 0.6 \mathrm{U}$ of Taq polymerase and $5 \mu \mathrm{l}$ of genomic DNA. The primers used for the amplification of the COI gene were FishF15'TCAACCAACCACAAAGACATTGGCAC3' and FishR1-5'TAGACTTC TGGGTGGCCAAAGAATCA3' (Ward et al., 2005). The thermal regime consisted of an initial step of $2 \mathrm{~min}$ at $95^{\circ} \mathrm{C}$ followed by 35 cycles of 40 $s$ at $94^{\circ} \mathrm{C}, 40 \mathrm{~s}$ at $54^{\circ} \mathrm{C}$ and $1 \mathrm{~min} 10 \mathrm{~s}$ at $72^{\circ} \mathrm{C}$ followed in turn by final extension of $10 \mathrm{~min}$ at $72^{\circ} \mathrm{C}$.

The PCR products were visualized on $1.5 \%$ agarose gels, and the most intense products were selected for sequencing. The cleaned up PCR product was sequenced by a sequencing facility (Bioserv Biotechnologies Pvt Ltd, Hyderabad, India).

\section{Sequence analysis}

The CO1 gene partial sequences of the four Nemipterus species were unambiguously edited using BioEdit sequence alignment editor 14 and aligned using CLUSTALW in BioEdit, and checked manually. Identical sequences were assigned in the same haplotype identity and only a single example of each species used in the phylogenetic divergences assuming that identical haplotypes shared the

Tab. 1. Threadfin bream fish species and their COI sequence Genbank accession numbers

\begin{tabular}{|c|c|c|c|}
\hline Sl. No & Scientific name & Common name & Accession number \\
\hline 1 & Nemipterus zysron & Slender threadfin bream & JN992287.1 \\
\hline 2 & Nemipterus nematophorus & Doublewhip threadfin bream & JN992286.1 \\
\hline 3 & Nemipterus bipunctatus & Delagoa threadfin bream & HQ423413.1 \\
\hline 4 & Nemipterus hexodon & Ornate threadfin bream & EF609414.1 \\
\hline 5 & Nemipterus furcosus & Fork-tailed threadfin bream & EF609413.1 \\
\hline 6 & Nemipterus japonicus 1 & Japanese threadfin bream & FJ347947.1 \\
\hline 7 & Nemipterus japonicus 2 & Japanese threadfin bream & EF609555.1 \\
\hline 8 & Nemipterus japonicus 3 & Japanese threadfin bream & EF609553.1 \\
\hline 9 & Nemipterus japonicus 4 & Japanese threadfin bream & HQ149889.1 \\
\hline 10 & Nemipterus japonicus 5 & Japanese threadfin bream & JN992288.1 \\
\hline 11 & Nemipterus mesoprion 1 & Mauvelip threadfin bream & EF609561.1 \\
\hline 12 & Nemipterus mesoprion 2 & Mauvelip threadfin bream & EF609559.1 \\
\hline 13 & Nemipterus mesoprion 3 & Mauvelip threadfin bream & EF609557.1 \\
\hline 14 & Nemipterus mesoprion 4 & Mauvelip threadfin bream & EF609560.1 \\
\hline 15 & Nemipterus virgatus 1 & Golden threadfin bream & FJ237835.1 \\
\hline 16 & Nemipterus virgatus 2 & Golden threadfin bream & FJ237835.1 \\
\hline 17 & Nemipterus virgatus 3 & Golden threadfin bream & FJ237837.1 \\
\hline 18 & Nemipterus virgatus 4 & Golden threadfin bream & FJ237839.1 \\
\hline 19 & Nemipterus peronii 1 & Notchedfin threadfin bream & EF609415.1 \\
\hline 20 & Nemipterus peronii 2 & Notchedfin threadfin bream & HQ149890.1 \\
\hline 21 & Nemipterus peronii 3 & Notchedfin threadfin bream & HQ149891.1 \\
\hline 22 & Lates calcarifer (Outgroup) & Seabass & EU189376.1 \\
\hline
\end{tabular}


same evolutionary origin. Haplotype definitions have been submitted to the NCBI GenBank (Acc. No. HQ423413, JN992286, JN992287, JN992288). To support the present data, selective CO1 sequences in other five Nemipterus species and one outgroup (Lates calcarifer) were retrieved from Genbank (Tab. 1). Nucleotide diversity, genetic variation and nucleotide composition and pairwise evolutionary distance among haplotypes was determined by the Kimura 2-Parameter method (Kimura, 1980) using the software program MEGA 3.1 (Molecular Evolutionary Genetics Analysis) (Kumar et al., 2004). The neighbourjoining $(\mathrm{NJ})$ and maximum likelihood (ML) trees were constructed using MEGA 3.1 and to verify the robustness of the internal nodes of these trees, bootstrap analysis was carried out using 1000 pseudoreplications.

\section{Results and discussion}

A total of 21 sequences were analysed from nine Nemipterus species in this study. Simplicity and un-ambiguity were observed among all the sequences and no introns, deletions or stop codons were observed any of the sequences. The sequence analysis revealed the average nucleotide frequencies as $\mathrm{A}=23.4 \pm 0.75 \%, \mathrm{~T}=31.6 \pm 1.17 \%, \mathrm{G}=18.0$ $\pm 0.60, C=26.9 \pm 0.76$ (Tab. 2 ). The average number of nucleotide difference $(\mathrm{K})=67.51$ and nucleotide diversity $(\mathrm{Pi})=0.1342$. Tajma's statistics $(\mathrm{D})=-0.1109$ and it was not significantly $(p<0.01)$ different among sequences. Kimura 2 Parameter (K2P) genetic distance in thread- fin bream fish species is given in Tab. 3. The overall K2P distance between the nine species was 0.109 . The K2P genetic distance was high $(0.150)$ between $N$. perinii and $N$. hexodon. Very low K2P distance (0.009) was exhibited between $N$. mesoprion and $N$. zysron.

The intra-species K2P distance (Fig. 1) was high in $N$. japonicus (0.069) followed by $N$. peronii (0.050) and $N$. mesoprion (0.002). The codon based genetic distance in nine Nemipterus species is depicted in Tab. 4 (below diagonal). Based on the CO1 sequence data, the codon based genetic distance was high $(0.372)$ between $N$. hexodon and $N$. nematophorus. The minimum level $(0.007)$ of codon based genetic distance was displayed between $N$. mesopri-

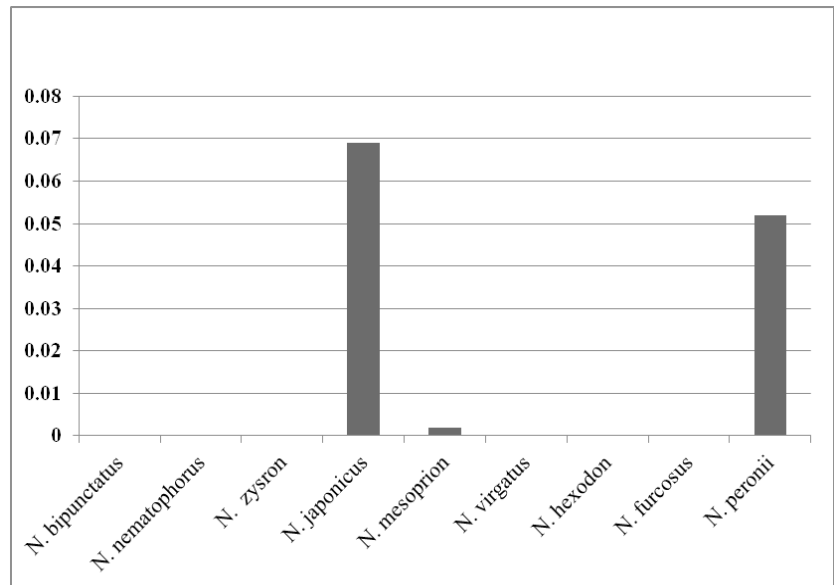

Fig. 1. Intra-species Kimura 2 Parameter (K2P) genetic distance in threadfin bream fish species

Tab. 2. Nucleotide base composition of threadfin bream fish species

\begin{tabular}{ccccccccc}
\hline Species & $\mathrm{A}$ & $\mathrm{T}$ & $\mathrm{G}$ & $\mathrm{C}$ & $\mathrm{GC}$ & $\mathrm{GC} \mathrm{1}$ & GC2 & GC3 \\
\hline N. zysron & 23.6 & 32.2 & 17.1 & 27.2 & 44.3 & 36.1 & 54.1 & 42.4 \\
N. nematophorus & 25.0 & 33.2 & 16.3 & 25.5 & 41.8 & 30.7 & 53.2 & 41.5 \\
N. bipunctatus & 23.7 & 32.3 & 18.6 & 25.4 & 44.0 & 33.8 & 54.9 & 43.4 \\
\hline N. hexodon & 24.3 & 30.5 & 18.2 & 27.0 & 45.2 & 38.4 & 54.6 & 42.7 \\
N. furcosus & 23.4 & 29.8 & 17.9 & 29.0 & 46.9 & 42.0 & 56.0 & 42.7 \\
N. japonicus & 23.1 & 32.4 & 17.8 & 26.8 & 44.7 & 35.4 & 56.4 & 42.7 \\
N. mesoprion & 22.7 & 32.7 & 18.4 & 26.2 & 44.6 & 36.2 & 55.1 & 42.7 \\
N. virgatus & 23.6 & 31.1 & 18.1 & 27.1 & 45.2 & 39.5 & 54.4 & 42.8 \\
N. peronii & 24.1 & 30.0 & 18.3 & 27.6 & 46.3 & 39.2 & 56.3 & 42.9 \\
\hline Mean & $23.4 \pm 0.75$ & $31.6 \pm 1.17$ & $18.0 \pm 0.60$ & $26.9 \pm 0.79$ & $44.7 \pm 1.45$ & $36.8 \pm 3.38$ & $55.0 \pm 1.07$ & $42.64 \pm 0.50$ \\
\hline
\end{tabular}

Tab. 3. Kimura 2 Parameter (K2P) genetic distance in threadfin bream fish species

\begin{tabular}{|c|c|c|c|c|c|c|c|c|c|}
\hline Species & $\begin{array}{c}N . \\
\text { zysron }\end{array}$ & $\begin{array}{c}N . \\
\text { nematophorus }\end{array}$ & $\begin{array}{c}N . \\
\text { bipunctatus }\end{array}$ & $\begin{array}{c}N . \\
\text { bexodon }\end{array}$ & $\begin{array}{c}N . \\
\text { furcosus }\end{array}$ & $\begin{array}{c}N . \\
\text { japonicus }\end{array}$ & $\begin{array}{c}N . \\
\text { mesoprion }\end{array}$ & $\begin{array}{c}N . \\
\text { virgatus }\end{array}$ & $\begin{array}{c}N . \\
\text { peronii }\end{array}$ \\
\hline N. zysron & $* * * *$ & & & & & & & & \\
\hline N. nematophorus & 0.075 & $* * * *$ & & & & & & & \\
\hline N. bipunctatus & 0.099 & 0.095 & $* * * *$ & & & & & & \\
\hline N. bexodon & 0.078 & 0.100 & 0.098 & $* * * *$ & & & & & \\
\hline N. furcosus & 0.133 & 0.140 & 0.122 & 0.142 & $* * * *$ & & & & \\
\hline N. japonicus & 0.133 & 0.133 & 0.141 & 0.138 & 0.122 & **** & & & \\
\hline N. mesoprion & 0.009 & 0.076 & 0.093 & 0.069 & 0.134 & 0.130 & $* * * *$ & & \\
\hline N. virgatus & 0.086 & 0.079 & 0.090 & 0.095 & 0.114 & 0.123 & 0.084 & $* * * *$ & \\
\hline$N$. peronii & 0.145 & 0.144 & 0.141 & 0.150 & 0.064 & 0.120 & 0.140 & 0.134 & $* * * *$ \\
\hline
\end{tabular}


16

Tab. 4. Codon based distance (below diagonal) and disparity index (above diagonal) in threadfin bream fish species

\begin{tabular}{|c|c|c|c|c|c|c|c|c|c|}
\hline Species & $\begin{array}{c}N . \\
\text { zysron }\end{array}$ & $\begin{array}{c}N . \\
\text { nematophorus }\end{array}$ & $\begin{array}{c}N . \\
\text { bipunctatus }\end{array}$ & $\begin{array}{c}N . \\
\text { bexodon }\end{array}$ & $\begin{array}{c}N . \\
\text { furcosus }\end{array}$ & $\begin{array}{c}N . \\
\text { japonicus }\end{array}$ & $\begin{array}{c}N . \\
\text { mesoprion }\end{array}$ & $\begin{array}{c}N . \\
\text { virgatus }\end{array}$ & $\begin{array}{c}N . \\
\text { peronii }\end{array}$ \\
\hline N. zysron & $* * * *$ & 0.161 & 0.107 & 0.085 & 0.000 & 0.000 & 0.000 & 0.000 & 0.011 \\
\hline N. nematophorus & 0.256 & $* * * *$ & 0.000 & 0.249 & 0.099 & 0.000 & 0.172 & 0.121 & 0.020 \\
\hline N. bipunctatus & 0.231 & 0.030 & **** & 0.171 & 0.087 & 0.000 & 0.121 & 0.082 & 0.000 \\
\hline N. bexodon & 0.185 & 0.372 & 0.292 & $* * * *$ & 0.000 & 0.050 & 0.158 & 0.000 & 0.000 \\
\hline N. furcosus & 0.093 & 0.262 & 0.233 & 0.030 & $* * * *$ & 0.000 & 0.000 & 0.000 & 0.005 \\
\hline N. japonicus & 0.075 & 0.060 & 0.060 & 0.206 & 0.111 & $* * * *$ & 0.000 & 0.000 & 0.000 \\
\hline N. mesoprion & 0.007 & 0.268 & 0.238 & 0.247 & 0.145 & 0.087 & **** & 0.000 & 0.024 \\
\hline N. virgatus & 0.044 & 0.221 & 0.195 & 0.062 & 0.010 & 0.070 & 0.081 & $* * * *$ & 0.000 \\
\hline N.peronii & 0.126 & 0.166 & 0.102 & 0.066 & 0.056 & 0.076 & 0.159 & 0.053 & $* * * *$ \\
\hline
\end{tabular}

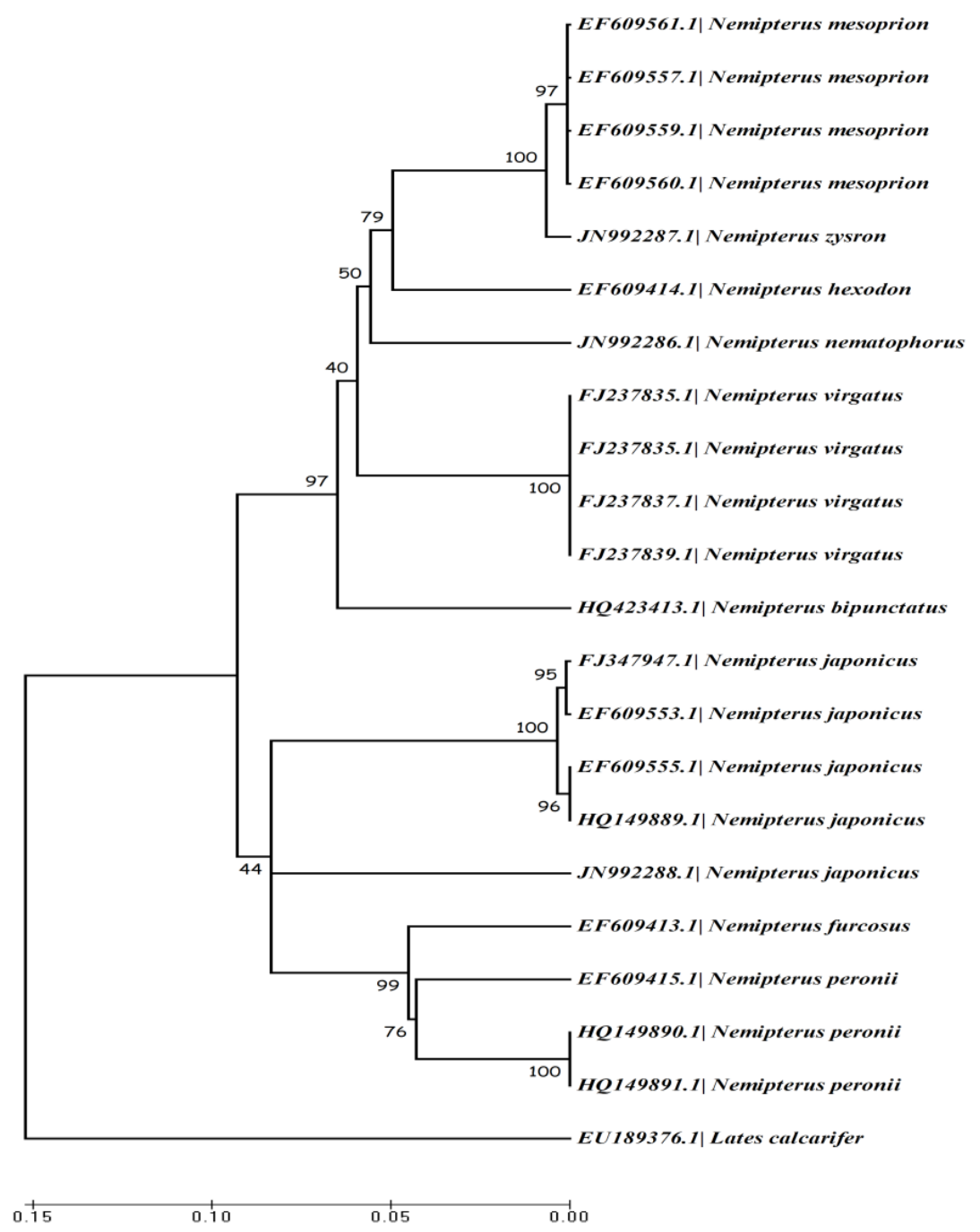

Fig. 2. Neighbour Joining (NJ) phylogenetic tree of threadfin bream fish species from COI gene sequences

on and N. zysron. The disparity index in nine Nemipterus species is displayed in Tab. 4 (above diagonal). The maximum disparity index (0.249) was observed between $N$. nematophorus and $N$. hexodon.

All the twenty two sequences were subjected in the phylogenetic analysis. The neighbour joining tree (NJ) and maximum likelihood tree (ML) of K2P distance were created to provide a graphical representation of the patterning of divergence of nine Nemipterus species (Fig. 2 and 3). As per NJ tree two distinct clads as two sub-trees within the same genus were recognized with high bootstrap value. Among the two sub-trees the larger one has an independent assemblage of $N$. mesoprion, $N$. zysron, $N$. hexodon, $N$. nematophorus, $N$. virgatus and $N$. bipunctatus 


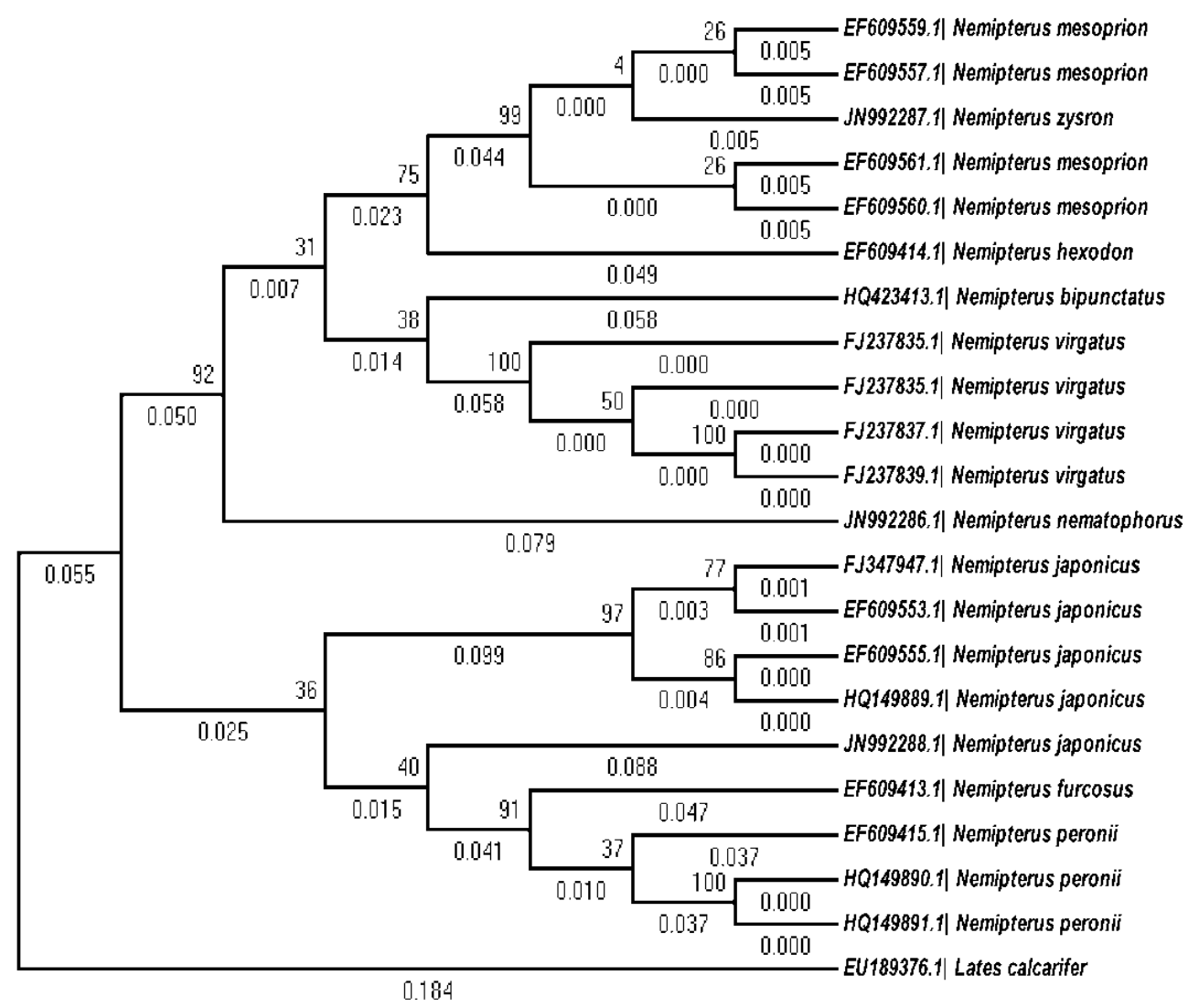

Fig. 3. Maximum likelihood (ML) phylogenetic tree of threadfin bream fish species from COI gene sequences

with $97 \%$ bootstrap value. Another clad representing all the other three species such as $N$.japonicus, $N$. furcosus and $N$. peronii with only $44 \%$ bootstrap value. The outgroup, Lates calcarifer was highly divergent and deviated in to a separate clad forming the root to the phylogenetic tree. The ML tree also showed the same type of divergence and formed two sub-trees having the bootstrap value of $92 \%$ and $36 \%$ respectively.

Species identification and phylogenetic relationship based on traditional methods and molecular methods are mostly concordant (Ward et al., 2005). In this study nine Nemipterus species were found genetically distinct from each other based on CO1 gene sequence which demonstrates simplicity and unambiguity. Morphologically very similar species like $N$. mesoprion, $N$. zysron and $N$. virgatus form a sister clad. Whereas, $N$. japonicus, $N$. furcosus and $N$. peronii form an independent sister clad in both $\mathrm{NJ}$ and ML trees of $\mathrm{CO} 1$ gene sequence. Estimates of genetic divergence from $\mathrm{CO} 1$ gene were sufficient to differentiate individuals of different threadfin bream species. In this study the level of intra-species variation was low which may be due to low number of haplotype identified in the sample with limited numbers collected for this study. Similarly, Lakra et al. (2011) reported very low intra-specific genetic divergence for scombroid fished and Ward et al. (2005) in many marine teleost species. Peris et al. (2009) also reported very low within species genetic distance for Indian carangid fishes.

Ward et al. (2005) reported an overall higher GC content in fishes based on complete MtDNA genome ranging from $38.4-43.2 \%$ and in $\mathrm{CO} 1$ alone it was $42.2-47.1 \%$, which reflects the $3^{\text {rd }}$ base variation. Peris et al. (2009) also reported considerable variation was exhibited in carangids in the $3^{\text {rd }}$ base position. In this study it has been observed the mean GC content was 36.8 (GC1)-42.6 (GC3) among the nine Nemipterus species. The range of K2P intra-specific genetic distance in the present study was 0.000-0.069, which was slightly higher when compared with the previous studies of Indian carangids, 0.000-0.015 (Peris et al., 2009), Australian fishes (Ward et al., 2005), North American Birds (Hebert et al., 2004), Moths (Hebert et al., 2003), and Primates (Hajibabaei et al., 2006). The mean nucleotide diversity $(\mathrm{Pi})$ among all the species was estimated as 0.1342 . In earlier studies it was estimated as 0.2029 in Indian marine fishes (Lakra et al., 2011). It has been shown that lineage diversity more quickly within species than between species (Pons et al., 2006).

An effective DNA-based identification system requires the satisfaction of three important conditions: it must be possible to recover the target DNA from all the species; the sequence information must be easily analysed; and the information content of the target sequence must be suf- 
18

ficient to enable species-level identification (Peris et al., 2009). All these three requirements were met in the present study, as all fish species examined could be recovered and targeted CO1 fragment aligned and analysed easily. Specimens of all species formed distinctive cluster and congruent with conventional morphological taxonomy. As per Ward et al. (2005), the COl analysis seeks only to delineate species boundaries yet there is some clear phylogenetic signal in $\mathrm{CO} 1$ sequence data, which is evident by the clustering of most of congeneric and confamilial species. The absolute clustering of conspecifics in the present study indicates the diagnostic ability of CO1 to correctly identify species.

\section{Conclusions}

The study has successfully proved the utility of COI divergences in identifying many of the Nemipterid fishes. The present analysis was not meant to be exhaustive, but to highlight the most important feature of COI based studies, that is the diagnostic ability of COI sequences in distinguishing closely related species and the intra-specific distances are lower than the inter-specific distances which was proved beyond doubt. The slight difference in the resolution factor in the present study and previous studies on Indian, Australian fishes and other groups of animals may be due to the low sample size. Further studies involving all the threadfin breams in the world and also by increasing the sample size in future studies will clarify the issue.

\section{References}

Hajibabaei M, Gregory A, Singer C, Hickey DA (2006). Benchmarking DNA barcodes: an assessment using available primate sequences. Genome 49:851-854

Hebert PDN, Cywinska A, Ball SL, Ward JR (2003). Biological identifications through DNA barcodes. Proc Royal Soc London, Ser B 270:313-322.

Hebert PDN, Penton EH, Burns JM, Janzen DH, Hallwachs W (2004). Ten species in one: DNA barcoding reveals cryptic species in the neotropical skipper butterfly Astraptes fulgerator. Proc Natl Acad Sci USA 101:14812-14817.

Hubert N, Hanner R, Holm E, Mandrak NE, Taylor E (2008). Identifying Canadian freshwater fishes through DNA barcodes. PLoS ONE 3(6):e2490.
Kimura M (1980). A simple method of estimating evolutionary rate of base substitutions through comparative studies of nucleotide sequences. J Molec Evol 16:111-120.

Kumar S, Tamura K, Nei M (2004). MEGA3: Integrated software for molecular evolutionary genetics analysis and sequence alignment. Brief Bioinfo 5:150-163.

Lakra WS, Verma MS, Goswami M, Lal KK, Mohindra V, Punia P, Gopalakrishnan A, Singh K V, Ward RD, Hebert $P$ (2011). DNA barcoding Indian marine fishes. Mol Ecol Res 11: 60-71.

Murthy VS, Vivekanandan E, Zacharia PU, Joshi KK, Manojkumar PP, Nair KVS, Gandhi V, Rajkumar U, Shoba, Kizhakundan J (2001). Development of management strategies for sustainable fishery of Threadin breams and silverbellies. CMFRI Ann Rep 37-39 p.

Pawar HB, Shirdhankar MM, Barvae SK, Patange SB (2011). Discrimination of Nemipterus japonicus (Bloch, 1791) stock from Maharashtra and Goa states of India. Ind J Geo Mar Sci 40(3): 471-475.

Peris M, Chandra Sekhar Reddy A, Rao LM, Khedkar GD, Ravinder K, Nasruddin K (2009). COI (Cytochrome oxidase-I) sequence based studies of Carangid fishes from Kakinada coast, India. Mol Biol Rep 36:1733-1740.

Pons J, Barraclough TG, Gomez-Zurita J, Cardoso A, Duran DP (2006). Sequence-based species delimitation for the DNA taxonomy of undescribed insects. System Biol 55:595-606

Russell BC (1990). Nemipterid fishes of the world, FAO Publications, Rome, 149 p.

Sambrook J, Fritsch EF, Maniatis T (1989). Molecular cloning: a laboratory manual, $2^{\text {nd }}$ Ed. Cold Spring Harbor Laboratory Press, Cold Spring Harbor, NY.

Thangaraj M, Lipton AP (2011). Assessment of genetic variation in closely related seahorse species (Genus: Hippocampus) using mtDNA marker. Ind J Biotech 10:140-142.

Thomson JM (1984). In FAO species identification sheets for fishery purpose, Western Indian Ocean fishing area. Fisher, $\mathrm{W}$ and Bianchi G (Eds.). FAO, Rome, Vol. 3.

Ward RD, Zemlac TC, Innes BH, Last PR, Hebert PDN (2005). DNA barcoding Australia's fish species. Philosoph Transact Royal Soc B, 360:1847-1857. 